\title{
ANALISIS GAYA BELAJAR PESERTA DIDIK SMP AL- AZHAR 32 PADANG SEBAGAI KRITERIA PENENTUAN PEMILIHAN STRATEGI PEMBELAJARAN
}

\author{
Amrianto $^{1(*)}$, M. Fazlan ${ }^{2}$ \\ Universitas Negeri Malang, Indonesia ${ }^{1}$ \\ Universitas Jambi, Indonesia ${ }^{2}$ \\ Amrianto20@gmail.com ${ }^{1}$, mfazlan05@gmail.com²
}

\begin{abstract}
Received: 21 November 2020 Revised: 26 November 2020 Accepted: 18 Januari 2021
\end{abstract}

\section{Abstract}

Berdasarkan konsep gaya belajar yang dimiliki peserta didik, maka peserta didik memiliki kekuatan dan kelemahan dalam belajar. Saat guru menerapkan gaya belajar yang tidak sesuai dengannya maka akan memepengaruhi hasil belajar. Oleh sebab itu penting kiranya untuk mengidentifikasi gaya belajar peserta didik. Salah satu sekolah di Kota Padang yaitu SMP Al-Azhar 32 Padang memiliki prestasi yang cukup banyak, walaupun termasuk sekolah swasta, namun tetap memiliki daya saing yang tinggi. Melihat prestasi yang dimiliki sekolah tersebut peneliti tertarik melakukan identifiksi gaya belajar peserta didik di sekolah tersebut. Penelitian ini merupakan penelitian deskriptif, dengan menggunkan teknik non-probability sampling. Sampel penelitian yaitu kelas VII A (Ar-Rahman) dengan 18 anggota kelas. Pengumpulan data dengan menggunakan angket identifikasi gaya belajar peserta didik. Hasil yang didapatkan bahwa 1) gaya belajar peserta didik kelas VII A (ArRahman) didominasi oleh peserta didik bergaya belajar visual, 2) guru tidak dapat menekankan hanya pada satu gaya belajar peserta didik, sebaiknya divariasikan, 3) penentuan gaya belajar yang akan digunakan juga tergantung pada karakteristik mata pelajaran tertentu, 4) penentuan model, metode dan media membutuhkan adanya identifikasi gaya belajar.

Keywords: Gaya Belajar; Visual; Pembelajaran

(*) Corresponding Author: Amrianto, amrianto@ gmail.com, +62 85367294192

How to Cite: Amrianto, \& Fazlan, M. (2021). Analisis Gaya Belajar Peserta Didik SMP Al-Azhar 32 Padang Sebagai Kriteria Penentuan Pemilihan Strategi Pembelajaran. Research and Development Journal of Education, 7 (1), 70-79.

\section{INTRODUCTION}

Peserta didik memiliki cara belajar sendiri-sendiri untuk lebih mudah dalam memahami pembelajaran yang berlangsung. Individu dalam belajar memiliki berbagai macam cara, ada yang belajar dengan cara mendengarkan, ada yang belajar dengan membaca, serta belajar dengan cara menemukan. Cara belajar peserta didik yang beraneka ragam tersebut dikenal sebagai gaya belajar (learning style) yang dipengaruhi oleh pengalaman, jenis kelamin, etnis (Philbin, dkk., 1995) dan secara khusus melekat pada setiap individu (Prastiti dan Pujiningsih, 2009).

Gaya belajar peserta didik dibagi menjadi tiga gaya belajar peserta didik, yaitu visual, audio dan kinestetik (Hamzah, 2008; Vhalery, Hartono, \& Leksono, 2019). Peserta didik mungkin memiliki ketiganya dalam mempelajari sesuatu, namun biasanya seorang anak akan memiliki satu gaya belajar yang lebih dominan (Hartati, 2015). Hal tersebut yang mendukung konsep bahwa setiap peserta didik memiliki gaya belajar yang unik (Ahmed, 2013). 
Peserta didik memiliki kekuatan dan kelemahan dalam belajar, seperti pada peserta didik dengan gaya visual perlu teks dan gambar dalam memahami, sedangkan gaya belajar audio membutuhkan penjelasan dan pendengaran untuk mengingat, dan sedangkan peserta didik gaya belajar kinestetik memerlukan adanya gerakan dan tindakan untuk mengingat. Sehingga dengan mengakomodasi gaya belajar maka peserta didik akan mampu belajar efektif dan efisien sehingga tujuan pembelajaran dapat tercapai (Rahayu dan Sibawaih, 2017).

Gaya belajar dapat menjadi salah satu alternatif untuk meningkatkan kemampuan peserta didik memahami suatu materi, satu anak akan mudah memahami materi-materi tertentu yang disajikan guru saat sesuai dengan kemampuan gaya belajar peserta didik (Bire, dkk., 2014). Suatu penelitian telah membuktikan bahwa gaya belajar mempengaruhi hasil belajar sebesar 32.1\% (Aini dan Sudira, 2015: 101).

O'Mahony, dkk., (2016) menyarankan perlunya mempertimbangkan gaya belajar individu untuk mengoptimalkan lingkungan belajar. Analisis gaya belajar individu sangat penting dalam meningkatkan pemahaman dan kinerja setiap peserta didik (Anbarasi, dkk., 2015). Analisis gaya belajar dan kecerdasan ini tidak hanya bermanfaat bagi guru saja tetapi juga untuk peserta didik. Peserta didik dapat mengetahui gaya belajarnya, kelemahan, dan kelebihan pada dirinya sehingga dapat dijadikan sebagai bahan evaluasi diri bagi peserta didik (Gilakjani, 2012: 110). Peserta didik yang telah mengetahui karakteristik gaya belajarnya sendiri maka mahapeserta didik akan lebih muda memotivasi dirinya dalam pembelajaran (Chatib, 2014: 171). Oleh sebab itu penting kiranya seorang guru untuk melakukan identifikasi gaya belajar, baik untuk peningkatan hasil belajar, juga dapat dilakukan perancangan pembelajaran lebih efektif untuk menyesuaikan dengan gaya belajar peserta didik. Tidak menuntut kemungkinan seorang anak memiliki hasil belajar yang rendah dipengaruhi dari metode pembelajaran yang tidak sesuai diberikan oleh guru untuk dirinya. Perlu disikapi kembali bagaimanakah cara pelaksanaan identifikasi gaya belajar dan manfaat identifikasi itu sendiri, sehingga timbul kesadaran akan pentingnya analisis gaya belajar bagi guru di sekolah.

Salah satu sekolah Kota Padang yaitu SMP Al-Azhar 32 memiliki prestasi yang cukup banyak, serta telah memiliki akreditasi sekolah A, walaupun sekolah ini masuk kedalam sekolah swasta, tetapi tidak kalah bersaing dengan sekolah negeri. Melihat prestasi yang didapatkan sekolah tersebut peneliti tertarik melakukan penelitian untuk mengidentifikasi dan melihat kecenderungan gaya belajar yang dimiliki peserta didik tersebut. Analisis gaya belajar penting untuk penentuan strategi pembelajaran yang cocok dan sesuai untuk peserta didik di SMP Al-Azhar 32 dalam mempertahankan dan meningkatkan kualitas pembelajaran di sekolah.

\section{LITERATURE REVIEW}

\section{Belajar dan Pembelajaran}

Menurut Zainal (2011: 1) belajar adalah perubahan tingkah laku seseorang akibat dari pengalaman dan latihan. Senada dengan hal tersebut Lufri (2007: 10) juga mendefinisikan belajar sebagai perubahan tingkah laku akibat dari interaksi dengan lingkungan. Sedangkan menurut Hosnan (2014: 7), belajar adalah proses interaksi suatu individu terhadap situasi yang ada di sekitarnya. Belajar menurut Suryabrata (2013: 232) terdiri dari beberapa hal pokok, salah satunya yaitu belajar membawa perubahan, perubahan terjadi karena adanya penguasaan keterampilan baru yang diakibatkan oleh adanya usaha. 
Belajar memiliki beberapa prinsip yang harus dipenuhi terutama bagi seorang guru dalam meningkatkan kreativitas peserta didik, prinsip-prinsip tersebut ialah sebagai berikut (Hosnan, 2014: 8-9).

1. Perhatian dan motivasi peserta didik, tanpa adanya perhatian dan motivasi belajar yang tinggi, seorang peserta didik akan cenderung memiliki kompetensi yang rendah.

2. Keaktifan, guru yang terlalu dominasi dalam pembelajaran akan menyebabkan peserta didik pasif selama pembelajaran. Peserta didik dituntut berbuat sesuatu, mempunyai kemauan dan aspirasi sendiri dalam pembelajaran.

3. Keterlibatan langsung, lebih menitikberatkan pada pembelajaran aktif yang menekankan pemecahan masalah dalam pembelajaran.

4. Pengulangan, pengulangan digunakan untuk melatih berbagai kemampuan peserta didik.

5. Tantangan, memberikan bahan pembelajaran yang menimbulkan rasa ingin tahu peserta didik.

6. Balikan dan penguatan, prinsip balikan dan penguatan mengarahkan peserta didik untuk sungguh-sungguh dalam belajar.

7. Perbedaan individual, bahwa setiap peserta didik memiliki perbedaan dengan yang lainnya.

Terdapat beberapa faktor yang mempengaruhi kualitas belajar peserta didik, faktor tersebut bisa dari luar dan bisa dari dalam peserta didik itu sendiri. Faktor dari luar meliputi faktor non sosial (seperti udara, suhu, dll) dan faktor sosial (sesama manusia), sedangkan faktor dari dalam yaitu faktor fisiologi dan psikologi (Suryabrata, 2013: 233234).

Pembelajaran adalah perpaduan antara konsep mengajar dan konsep belajar (Darmansyah, 2010: 39-40). Senada dengan hal tersebut menurut Lufri (2007: 10) pembelajaran merupakan segala upaya yang digunakan untuk menciptakan peristiwa belajar dari dalam peserta didik. Selain itu pembelajaran juga diartikan sebagai cerminan dari pengalaman masa lalu yang mempengaruhi perilaku suatu individu atau kelompok (Huda, 2014: 6). Sedangkan menurut Irham dan Wiyani (2016: 131) pembelajaran adalah sebuah aktivitas yang dilaksanakan oleh guru dalam mengkondisikan lingkungan belajar dengan baik, serta hubungannya terhadap peserta didik apakah terjadi proses belajar di dalam dirinya atau tidak.

Menurut Zainal (2011: 19-20), hakikat pembelajaran adalah perubahan baik tingkah laku, pengetahuan maupun keterampilan. Pembelajaran berperan dalam mengembangkan kemampuan peserta didik menuju kedewasaan (Irham dan Wiyani, 2016: 132). Proses pembelajaran itu sendiri terdiri dari persiapan, penyampaian, pelatihan dan penampilan akhir (Darmansyah, 2010: 51-53).

Pembelajaran memiliki beberapa komponen yang harus terpenuhi, yaitu salah satunya media pembelajaran. Media pembelajaran dituntut bersifat fleksibel, fleksibel dalam arti dapat mengatasi keterbatasan waktu, ruang dan indra dalam tercapainya pembelajaran yang efektif dan maksimal (Andromeda, dkk., 2018: 8), terutama dalam penyajian gambar, gambar harus jelas dan dapat menjelaskan konsep materi yang harus dipahami peserta didik (Oktarina, dkk., 2018: 8). Selain itu terdapat komponen lain dalam proses pembelajaran yaitu tujuan, materi, strategi dan metode dan evaluasi (Darmansyah, 2010: 51-53).

\section{Gaya Belajar}

Gaya belajar merupakan suatu kombinasi dari bagaimana seseorang menyerap, dan kemudian mengatur serta mengolah informasi. Gaya belajar bukan hanya berupa aspek 
ketika menghadapi informasi, melihat, mendengar, menulis dan berkata tetapi juga aspek pemrosesan informasi sekunsial, analitik, global atau otak kiri-otak kanan, aspek lain adalah ketika merespon sesuatu atas lingkungan belajar (diserap secara abstrak dan konkret) (Willingham, dkk., 2015).

Gaya belajar seseorang adalah kombinasi dari bagaimana seseorang menyerap dan mengatur serta mengolah informasi. Beberapa penelitian mengenai gaya belajar menunjukkan bahwa (1) beberapa pelajar mempunyai kebiasaan belajar yang berbeda dengan yang lainnya, (2) beberapa pelajar belajar lebih efektif bila diajar dengan metode yang paling disukai, dan (3) prestasi pelajar berkaitan dengan bagaimana caranya belajar (Riding \& Rayner, 1998).

James (dalam Wiyono, dkk., 2012), gaya belajar didefinisikan sebagai kebiasaan belajar dimana seseorang merasa paling efisien dan efektif dalam menerima, memproses, menyimpan dan mengeluarkan sesuatu yang dipelajari. DePorter, dkk., (2014) menemukan banyak variabel yang mempengaruhi cara belajar orang yang mencakup faktor-faktor fisik, emosional, sosiologis dan lingkungan.

Gaya belajar peserta didik dibagi menjadi tiga gaya belajar peserta didik, yaitu visual, audio dan kinestetik (Hamzah, 2008). Terkait hal tersebut, peserta didik memliki ciri-ciri tersen diri dan perlu disikapi terhadap gaya belajar yang mereka miliki, berikut dijelaskan tentang pembelajaran untuk peserta didik berdasarnakn gaya belajar peserta didik itu sendidi.

\section{Pembelajaran untuk Peserta Didik Visual}

Peserta didik yang sangat visual memiliki beberapa ciri sebagai berikut (DePorter, dkk., 2014: 123):

1. Teratur, memperhatikan segala sesuatu, menjaga penampilan;

2. Mengingat dengan gambar, lebih suka membaca daripada dibacakan; dan

3. Membutuhkan gambaran dan tujuan menyeluruh.

Dengan demikian, maka beberapa karakteristik pembelajaran yang sesuai untuk peserta didik yang sangat visual adalah sebagai berikut:

1. Pendidik berdiri tenang saat menyajikan segmen informasi, dan bergeraklah perlahan di antara segmen tersebut;

2. Beri dorongan pada peserta didik untuk menggambarkan informasi, dengan membuat diagram, simbol dan gambar berwarna dalam catatan peserta didik Visual;

3. Adanya Tabel dan Grafik akan memperdalam pemahaman peserta didik Visual terutama dalam matematika, teknik, atau IPA;

4. Adanya pembuatan Peta pikiran/ peta konsep akan sangat membantu

5. Peserta didik Visual dalam memberikan "gambaran keseluruhan" suatu konsep;

6. Gunakan bahasa simbol visual dalam presentasi dosen yang mewakili konsep kunci;

7. Membiasakan peserta didik untuk mencatat kembali materi/informasi dengan menggunakan aneka warna/gambar yang menarik;

8. Perhatikan penerangan atau pencahayaan ruang saat belajar/pembelajaran berlangsung.

9. Gunakan media pembelajaran berupa Buku, majalah, Poster, Komputer/LCD, Kolase, Flow chart, Highlighting, kata kunci yang dipajang di sekeliling kelas, tulisan dengan warna menarik.

\section{Pembelajaran untuk Peserta Didik Auditorial}

Peserta didik yang sangat auditorial memiliki beberapa ciri sebagai berikut (DePorter, dkk., 2014: 124):

1. Perhatiannya mudah terpecah; 
2. Berbicara dengan pola berirama;

3. Belajar dengan cara mendengarkan, menggerakkan bibir/bersuara saat membaca;

4. Berdialog secara internal dan eksternal.

Sesuai dengan ciri peserta didik auditorial tersebut, berikut ini beberapa karakteristik pembelajaran yang sesuai:

1. Berikan informasi secara berulang-ulang, dapat memanfaatkan metode tanya jawab;

2. Gunakan teknik pengulangan, minta peserta didik untuk menyebutkan kembali konsep dan petunjuk;

3. Dosen menggunakan variasi vokal dalam presentasi;

4. Nyanyikan konsep kunci atau mintalah peserta didik untuk membuat lagu terkait konsep tersebut;

5. Beri dorongan pada peserta didik untuk membuat/memikirkan "jembatan keledai" untuk mempermudah menghafalkan/ mengingat konsep kunci;

6. Gunakan teknik tanya jawab;

7. Menggunakan metode tanya jawab, bermain peran, kerja kelompok, teknik mnemonics;

8. Melibatkan musik dalam pembelajaran.

\section{Pembelajaran untuk Peserta Didik Kinestetik}

Gerakan, koordinasi, irama, tanggapan emosional, dan kenyamanan fisik sangat menonjol pada peserta didik yang sangat kinesterik. Sesuai dengan yang diungkapkan dalam DePorter, dkk., (2014:124) bahwa beberapa ciri seseorang yang kinestetik antara lain:

1. Sering menyentuh orang, berdiri berdekatan, dan bergerak saat berinteraksi dengan orang lain;

2. Belajar dengan melakukan;

3. Menunjuk tulisan saat membaca;

4. Mengingat sambil berjalan dan melihat.

Oleh karena itu, berikut ini beberapa karakteristik pembelajaran yang sesuai dengan peserta didik yang sangat kinestetik, antara lain:

1. Peserta didik kinestetik lebih menyukai tugas berupa proyek terapan;

2. Gunakan media pembelajaran/ alat bantu saat mengajar untuk menimbulkan rasa ingin tahu dan menekankan konsep kunci;

3. Ijinkan peserta didik kinestetik untuk berjalan-jalan di kelas.

\section{METHODS}

Penelitian ini merupakan penelitian deskriptif, yang menggambarkan jenis-jenis gaya belajar yang dimiliki peserta didik selama di sekolah. Teknik sampel dengan cara non-probability sampling, peneliti menggunakan random kelas, kelas yang digunakan adalah satu kelas, yang dalam hal ini peneliti melakukan penelitian di kelas VII A (ArRahman) SMP Al-Azhar 32 Padang yang beranggotakan 18 peserta didik. Waktu penelitian pada bulan maret 2018 .

Instrumen penelitian menggunakan instrumen angket identifikasi gaya belajar merujuk dari Buku Online "Belajar Otodididak Sampai Mati" karangan Ahmad Zamhari Hasan. Buku tersebut merujuk dari buku "Revolusi Cara Belajar" karya Gordon Dryden \& Jeannete Vos (empat gaya belajar), diperbaiki dengan buku "Cara Belajar Cepat Abad 21" karya Colin Rose \& Malcolm J. Nicholl (menjadi 3 gaya belajar karena 
pembelajar taktil dan kinestetik sama). Analisis data menggunakan statistic dengan rumus persentase.

\section{RESULTS \& DISCUSSION}

\section{Results}

Berdasarkan analisis angket identifikasi gaya belajar maka didapatkan hasil yang mendominasi adalah visual, kemudian kinestetik, audio dan ada yang memiliki dua gaya belajar sekaligus yaitu gaya belajar visual dan kinestetik, data tersebut dapat dilihat pada tabel 1 .

Tabel 1.

Distribusi Gaya Belajar Peserta Didik

\begin{tabular}{cccc}
\hline No. & Gaya Belajar & Peserta Didik & Persentase \\
\hline 1 & Visual & 10 & $55,56 \%$ \\
2 & Audio & 2 & $11,11 \%$ \\
3 & Kinestetik & 5 & $27,78 \%$ \\
4 & Visual dan Kinestetik (Kombinasi) & 1 & $5,56 \%$ \\
& Total & 18 & $100 \%$ \\
\hline
\end{tabular}

Sumber: Peneliti (2020)

\section{Discussion}

Beberapa kasus setiap anak memiliki beberapa ciri-ciri prilaku yang dapat diamati oleh guru sebagai pertimbangan untuk mengidentifikasi gaya belajar, seperti pada penyelesaian masalah matematika, gaya belajar peserta didik visual memahami dengan gerakan mata yang cepat serta mengarah ke bawah, sering mencoret-coret dan merancang dengan teratur, dan sedangkan peserta didik dengan gaya belajar auditoria bersuara pelan dalam membaca soal, dan sering berbicara sendiri dalam memecahkan soal dan sesekali terlihat berpikir dengan menadah ke arah atas, dan saat menuliskan hasil cenderung raguragu. Kemudian gaya kinestetik, membaca lembar soal sambil memainkan pensil di tangannya, saat berpikir peserta didik cenderung melipat pojok soal, ketika menemukan hasil atau pemecahan masalah sesekali sambil menulis tangannya menggaruk pipinya (Firdaus, 2016). Hal tersebut merupakan hal yang dapat diamati dengan mata, namun kita dapat juga menggunakan angket dalam mengidentifikasi gaya belajar peserta didik bila merasa ragu dengan pengamatan tersebut.

Berdasarkan hasil penelitian maka didapatkan bahwa peserta didik dominan pada gaya belajar visual dengan $56 \%$, hal tersebut menandakan bahwa peserta didik dalam kelas tersebut lebih mudah dalam memahami gambar-gambar visualisasi. Namun dalam penelitian ini ditemukan adanya peserta didik dengan dua gaya belajar. Hal tersebut wajar, karena pada dasarkan peserta didik memiliki ketiga gaya belajar tersebut, namun pengembangan dari masing-masing individu pasti berbeda, sehingga tidak mutup kemungkinan akan ada teridentifikasi dalam satu anak terdiri dari dua bahkan tiga gaya belajar. Walaupun gaya belajar visual lebih banyak ditemukan pada kelas, sebaiknya guru tidak hanya menggunakan satu gaya belajar dalam pembelajaran karena bisa saja terjadi kejenuhan atau penurunan hasil belajar dari peserta didik bergaya belajar berbeda, sebaiknya metode, media dan model pembelajaran divariasikan.

Terkait penentuan model pembelajaran tentu disesuaikan juga dengan materi atau mata pelajaran yang akan diajarkan. Gaya belajar juga dipengaruhi oleh karakteristik mata pelajaran (Zahri, dkk., 2017). Beberapa penelitian juga ikut menghubungkan gaya 
belajar terhadap materi pembelajaran seperti pada materi fisika, anak dengan gaya belajar audio memilki prestasi belajar lebih tinggi dibandingkan anak dengan gaya belajar visual dan kinestetik (Halim, 2017). Pada mata pelajaran matematika didapatkan yang memiliki prestasi lebih baik adalah pada peserta didik dengan gaya belajar visual, disusul audio, kemudian kinestetik (Kuslaila, ddk. 2016). Sedangkan pada mata pelajaran PAI peserta didik visual lebih berprestasi dibandingkan dengan peserta didik dengan gaya belajar kinestetik (Sahimin, dkk., 2017), serta juga pernah dilakukan penelitian gaya belajar terhadap hasil belajar dalam mata kuliah di perguruan tinggi, yaitu pada ilmu alam dasar dan mendapatkan hasil adanya hubungan yang signifikan dari variabel tersebut (Wicaksono, 2016).

Penentuan gaya belajar ini tentu tidak lepas dari tujuan utamanya yaitu peningkatan hasil belajar peserta didik. Menurut penelitian Ansela (2016), gaya belajar memiliki hubungan positif terhadap hasil belajar. Hal yang sama juga ditemukan oleh Cahyaningtyas dan Hakim (2017) menyatakan bahwa gaya belajar sangat mendukung peningkatan penguasaan kosakata bahasa inggris, dan dari peningkatan kosakata tersebut juga dapat meningkatkan kemampuan komputer peserta didik. Bahkan pada penelitian Nurlia, dkk. (2017), mendapatkan bahwa gaya belajar memiliki hubungan yang kuat (tinggi) terhadap hasil belajar peserta didik. Dengan kata lain gaya belajar menentukan keberhasilan peserta didik dalam menguasai sesuatu, penggunaan gaya belajar yang tepat dapat membantu peserta didik dalam menguasai pembelajaran.

Pada dasarnya gaya belajar merupakan salah satu faktor penentu hasil belajar peserta didik, namun masih banyak faktor lain yang mempengaruhi hasil belajar peserta didik, dari penelitian Syukur dan Misu (2016) gaya belajar hanya menyumbang $12 \%$ dalam hasil pembelajaran matematika, hal tersebut menandakan bahwa masih banyak faktor yang mampu mempengaruhi hasil belajar peserta didik. Selain itu banyak faktor yang sejalan mempengaruhi hasil belajar peserta didik salah satunya motivasi belajar. Motivasi dan gaya belajar menyumbang adanya dampak positif dalam pembelajaran (Wibowo, 2018). Selain itu gaya belajar juga sering diselaraskan dengan kemandirian peserta didik (Dedi, dkk., 2016), dan dengan metakognisi peserta didik (Hasniati, dkk., 2017).

Arsana (2011) lebih menyarankan agar dalam menentukan model dan metode belajar peserta didik sebaiknya dilakukan identifikasi karakteristik peserta didik terutama gaya belajar, sehingga dapat lebih mengoptimalkan proses pembelajaran. Dalam memenuhi adanya tuntutan gaya belajar, gaya belajar sering dikolaborasikan dengan model ataupun pendekatan, seperti pada penelitian Rahayu dan Istiani (2017), yang mengkolaborasikan gaya belajar dengan pendekatan kontekstual dan ditemukan adanya peningkatan dari hasil belajar peserta didik. Selain itu bahkan gaya belajar VAK telah dikembangkan menjadi model pembelajaran, seperti pada penelitian (Suryadin, dkk., 2017) yang melihat pengaruh model pembelajaran VAK, dan hasilnya berpengaruh pada hasil belajar peserta didik.

\section{CONCLUSION}

Berdasarkan hasil penelitian dan pembahasanmaka dapat ditarik kesimpulan sebagai berikut ini:

1. Gaya belajar peserta didik kelas VII A (Ar-Rahman) didominasi oleh peserta didik bergaya belajar visual.

2. Guru tidak dapat menekankan hanya pada satu gaya belajar peserta didik, sebaiknya divariasikan. 
3. Penentuan gaya belajar yang akan digunakan juga tergantung pada karakteristik mata pelajaran tertentu. belajar.

Penentuan model, metode dan media membutuhkan adanya identifikasi gaya

\section{REFERENCES}

Ahmed, J. (2013). How different are students and their learning styles?. International Journal of Research in Medical Sciences, 1(3), 212.

Aini, S. N., \& Sudira, P. (2015). Pengaruh strategi pembelajaran, gaya belajar, sarana praktik, dan media terhadap hasil belajar patiseri SMK se-Gerbangkertasusila. Jurnal Pendidikan Vokasi, 5(1), 88-102.

Anbarasi, M., Rajkumar, G., Krishnakumar, S., Rajendran, P., Venkatesan, R., Dinesh, T., ... \& Venkidusamy, S. (2015). Learning style-based teaching harvests a superior comprehension of respiratory physiology. Advances in physiology education.

Andromeda, A., Lufri, Festiyed, Allizar, E., Iryani, I, Guspatni, G., Fitri, L. (2018). Validity and Practicality of Experiment Integrated Guided Inquiry-Based Module on Topic of Colloidal Chemistry for Senir High School Learning. In IOP Conference Series: Materials Science and Engineering, 335(1), p. 012094. IOP Publishing.

Ansela. (2016). Pengaruh Gaya dan Motivasi terhadap Hasil Belajar Marketing Kelas X Pemasaran SMK Immanuel, Untan Pontianak.

Arsana, I.W. (2011). Pengaruh Strategi Pembelajaran terhadap Hasil Belajar Pendidikan Kewarganegaraan Peserta didik Kelas V yang memiliki Kecerdasan Emosional dan Gaya Belajar yang Bebeda di Kecamatan Rendang, Karang , Bali, Jurnal Universitas PGRI Adi Buana Surabaya, 13: 1-12.

Bire, A. L., Geradus, U., dan Bire, J. (2014). Pengaruh Gaya Belajar Visual, Auditorial, dan Kinestetik terhadap Prestasi Belajar Siswa. Jurnal Kependidikan: Penelitian Inovasi Pembelajaran, 44(2).

Cahyaningtyas, D. (2017). Pengaruh Penguasaan Kosakata Bahasa Inggris, Manajemen Waktu dan Gaya Belajar terhadap Hasil Belajar Aplikasi Komputer pada Mahapeserta didik Pendidikan Akuntansi Fakultas Ekonomi Universitas Negeri Surabaya, Jurnal Pendidikan Akutansi, 1(1): 1-8.

Chatib, Munif. (2014). Orangtuanya Manusia: Melejitkan Potensi dan Kecerdasan dengan Menghargai Fitrah Setiap Anak. Bandung: PT Mizan Pustaka.

Darmansyah. (2010). Pembelajaran Berbasis Web: Teori, Konsep dan Aplikasi. Padang: UNP Press.

Dedi, S.R., dkk. (2016). Pengaruh Motivasi Belajar, Gaya Belajar dan Kemandirian Belajar terhadap Hasil Belajar Mahapeserta didik S! PGSD Masukan Sarjana Di UPBJJ UT Bandung, Edu Humaniora, 8(2): 163-177.

DePorter, Bobbi, Mark Reardon, \& Sarah Singer-Nourie. (2014). Quantum Teaching. Bandung: PT Mizan Pustaka.

Firdaus, H.P.E. (2016). Analisis Proses Menyelesaian Masalah Matematika berdasarkan Gaya Belajar Peserta didik Sekolah Dasar pada Materi Operasi Perkalian dan Pembagian Pecahan, Universitas Muhammadiyah Jember.

Gilakjani, A. P. (2012). Visual, auditory, kinaesthetic learning styles and their impacts on English language teaching. Journal of studies in education, 2(1), 104-113.

Halim, A. (2017). Pengaruh Strategi Pembelajaran dan Gaya Belajar terhadap Hasil Belajar Fisika, Jurnal Teknologi Pendidikan, 10(2): 98-108. 
Hamzah, (2008). Orientasi Baru dalam Psikologi Pembelajaran. Jakarta: PT Bumi Aksara.

Hartati, L. (2015). Pengaruh gaya belajar dan sikap siswa pada pelajaran matematika terhadap hasil belajar matematika. Formatif: Jurnal Ilmiah Pendidikan MIPA, 3(3): 224-235.

Hasan, H.Z.___ Buku Online Belajar Otodidak Sampai Mati, (Online), (https://sampenulis.wordpress.com/anda-mau-tahu-gaya-belajar-dan-kecerdasanberganda-isilah/, diakses 12 Maret 2018).

Hasniati, N., dkk. (2017). Hubungan Motivasi Belajar, Gaya Belajar dan Kesadaran Metakognitif dengan Hasil Belajar Biologi Peserta didik Kelas XI IPA SMA Negeri di Kabupaten Soppeng, Journal of Biological Education, 1(1): 15-22.

Hosnan. (2014). Pendekatan dan Kontekstual dalam Pembelajaran Abad 21. Jakarta: Ghalia Indonesia.

Huda, H. (2014). Model-model Pengajaran dan Pembelajaran. Yogyakarta: Pusta Pelajar.

Irham, M., dan Wiyani, N. A. (2016). Psikologi Pendidikan: Teori dan Aplikasi dalalm Proses Pembelajaran. Yogyakarta: Ar-Ruzz Media.

Kuslaila, M., dkk. (2016). Eksperimentasi Model Pembelajaran Pair Checks pada Materi Pokok Segitiga ditinjau dari Gaya Belajar Peserta Didik, Jurnal Ilmiah Pendidikan Matematika, 2(2): 110-115.

Lufri. (2007). Strategi Pembelajaran Biologi. Padang: UNP Press.

Nurlia, dkk. (2017). Hubungan Antara Gaya Belajar, Kemandirian Belajar dan Minat Belajar dengan Hasil Belajar Biologi Peserta didik, Jurnal Pendidikan Biologi, 6(2): 321-328.

Oktarina, K., Lufri, dan Chatri, M. (2018). Validity of Learning Module Natural Sciences Oriented Contructivism with the Contain of Character Education for Students of Class VIII at Yunior High School. In IOP Conference Series: Materials Science and Engineering, 335(1), p. 012094. IOP Publishing.

O'Mahony, S. M., Sbayeh, A., Horgan, M., O'Flynn, S., \& O'Tuathaigh, C. M. (2016). Association between learning style preferences and anatomy assessment outcomes in graduate-entry and undergraduate medical students. Anatomical sciences education, 9(4), 391-399.

Philbin, M., Meier, E., Huffman, S., \& Boverie, P. (1995). A survey of gender and learning styles. Sex roles, 32(7-8), 485-494.

Prastiti, S. D., \& Pujiningsih, S. (2009). Pengaruh faktor preferensi gaya belajar terhadap prestasi belajar mahasiswa akuntansi. Jurnal ekonomi bisnis, 14(3), 224-231.

Rahayu, A.T., dan Sibawaih, I. (2017). Pembelajaran Bahasa Inggris yang Menyenangkan melalu Pemahaman Gaya Belajar Peserta didik, Jurnal Ilmiah Pendidikan, 4(2): 193-200.

Rahayu, S. Dan Istiani, A. (2017). Pembelajaran Matematika melelaui Pendekatan Kontekstual dengan Gaya Belajar VAK (Visual Auditory Kinestetik), Jurnal Edumath, 3(2): 129-137.

Riding, R., \& Rayner, S. (1998). Cognitive styles and learning strategies. London: David Fulton Publisher.

Sahimin, dkk. (2017). Pengaruh Model Pembelajaran dan Gaya Belajar terhadap Hasil Belajar Peserta didik Kelas VII SMP Negeri 1 Kabanjahe Kabupaten Karo, Edu Riligia, 1(2): 152-163.

Suryabrata, S. (2013). Psikologi Pendidikan. Jakarta: RajaGrafindo Persada.

Suryadin, dkk. (2017). Pengaruh Model Pembelajaran Visual Auditorial Kinestetik (VAK) terhadap Motivasi dan Hasil Belajar IPA Biologi Peserta didik Kelas VIII SMP Negeri 3 Gunungsari Tahun Ajaraan 2015/2016, J. Pijar MIPA, 12(1): 19-24. 
Syukur, M., dan Misu, L. (2016). Hubungan antara Gaya Belajar dengan Hasil Belajar Matematika Peserta didik Kelas XI SMAN 4 Kendari, Jurnal Penelitian Pendidikan Matematika, 4(2): 153-167.

Vhalery, R., Hartono, D., \& Leksono, A. W. (2019). Kontribusi Gaya Belajar Pada Aktivitas Belajar Matematika Ekonomi. Jurnal Pendidikan Ekonomi, 12(2), 78-86.

Wibowo, W.A. (2018). Pengaruh Gaya Belajar, Tingkat Pendapatan Orang Tua dan Motivasi Belajar terhadap Prestasi Mahapeserta didik Pendidikan Ekonomi Universitas Negeri Yogyakarta, Jurnal Pendidikan dan Ekonomi, 7(1): 79-86.

Wicaksono, A.G. (2016). Korelasi Motivasi Belajar dan Gaya Belajar dengan Prestasi Belajar Ilmu Alamiah dasar Mahapeserta didik Prodi PGSD Universitas Slamet Riyadi Surakarta Tahun Akademik 2015/2016, Profesi Pendidikan Dasar, 3(2): 121-125.

Willingham, D. T., Hughes, E. M., \& Dobolyi, D. G. (2015). The scientific status of learning styles theories. Teaching of Psychology, 42(3), 266-271.

Wiyono, K., Setiawan, A., \& Paulus, C. T. (2012). Model multimedia interaktif berbasis gaya belajar untuk meningkatkan penguasaan konsep pendahuluan Fisika zat padat. Jurnal Pendidikan Fisika Indonesia, 8(1).

Zahri, T.N. dkk. (2017). Hubungan Gaya Belajar dan Keterampilan Belajar denga Hasil Belajar Mahapeserta didik, Konselor. 6(1): 18-23.

Zainal, A. 2011. Micro Teaching. Jakarta: Rajawali Pres. 